\title{
Consumers' preferences for household articles prepared from synthetic leather waste
}

\author{
NIDHI KALIA AND VANDANA GANDOTRA
}

Received: 30.11.2015; Revised: 03.05.2016; Accepted: 13.05.2016

See end of the paper for authors' affiliations

\section{VANDANA GANDOTRA}

Department of Apparel and Textile

Science, Punjab Agricultural

University, LUDHIANA (PUNJAB)

INDIA

Email : gandotra_vandana@yahoo.

co.in
ABSTRACT : The concept of designing household articles using synthetic leather waste is useful for designing different household articles, accessories and apparels. The present study was undertaken for design development of household articles using synthetic leather waste. The preferences of sixty women purposively selected from Ludhiana city were taken for development of household articles from synthetic leather waste. Television was an important source of information regarding new fashion trends in household articles. Intricacy of design was the most important feature considered by respondents while purchasing household articles. The largest percentages of respondents preferred velvet as a base material for cushion cover, blend of cotton and polyester for table mat, polyester as base material for curtain, khaddar casement for dining sheet, cotton fabric for lamp shade and corduroy as a base material for pocket hanger. Tassels were the most preferred embellishment for household articles by the majority of the respondents.

KEY WORDS: Designing, Articles, Household articles, Synthetic leather waste, Preferences

- HOW TO CITE THIS PAPER : Kalia, Nidhi and Gandotra, Vandana (2016). Consumers' preferences for household articles prepared from synthetic leather waste. Asian J. Home Sci., 11 (1) : 157-160, DOI: 10.15740/HAS/AJHS/11.1/157-160. 